\title{
Annotated Guide to Internet Resources on Trafficking in Women
}

\author{
Kelly Mannix and Ayesha Shamim
}

Abstract

A carefully selected introduction to current research available on the Internet about trafficking in women, this annotated list contains international responses to the global scope of the flesh

trade. Articles contain vivid accounts of

the violence, degradation and poverty inherent in sexual exploitation, and provide analysis and possible courses of action. Hundreds of websites offering research and promoting activism to combat global prostitution and trafficking already exist and more are being created. Some of the resources are located on "gateway sites," which contain valuable links to related sites.

Precis

Une introduction prudemment selective des recherches detaillees sur la traite des blanches presentement disponibles sur Internet. Cette liste annotee de sources demontre clairement I' ampleur du rayonnement au plan global du commerce de la chair. Les articles contiennent des descriptions saisissantes de la pauvrete, de la violence et de la degradation inherentes a I' exploitation sexuelle, et

fournissent des analyses ainsi qu'un aperr; $u$ des solutions envisageables. Des centaines de sites presenten $t$ des resultats de recherches et font la promotion de l' activisme con tre la globalisation de la prostitution, et leur nombre ne cesse de cro/tre. Certaines de ces ressources sont localisees sur des «sites $d$ ' entree» (gateway sites)

KElly Mnnnix holds a Mnster oflnformntion Studies from the University of Toronto and is responsible for electronic communication and research for the International Women's Rights Project of the Centre for Feminist Research, York University, Toronto.

A yesha Shamin holds a Mnster in Economics from York

A yesha Shamin holds a Mnster in Economics from York
University, Toronto, and provides research and University, Toronto, and provides research and communications support for the International Women's
Rights Project of the Centre for Feminist Research, York University, Toronto.

Refuge, Vol. 17, No. 5 (November 1998) qui contiennent d'utiles liens vers des sites complementaires.

Adams, Barbara. 1997 . "How Long Must We Wait?" People's Review. http://www.bena.com/nepaltrek/ adams/ ad70227.html

[August 14, 1998]

A description of trafficking and sexual exploitation in Nepal, the article also explains in vivid detail the impact of sexual slavery on India and cites statistics charting a frightening increase of trafficking on the Subcontinent. In conclusion, a strong call for action is sounded.

Caldwell, Gillian, Steven Galster, and Nadia Steinzor. 1997. Crime and Servitude: An Expose of Traffic in Women for Prostitution from the Newly Independent

States. Global Survival Network. http://www.globalsurviva1.net/

femaletrade/9711russia.htm

[August 5,1998]

Declaring trafficking a problem which transcends na tional borders, the report explores various factors which allow global trafficking to thrive, despite current prohibitions. According to Anastasia Posadskaya- Vanderbeck, the Founding Director of the Moscow Centre for Gender Studies, this report represents a "critical first step toward developing co-operative and transnational relationships to address this massive violation of human rights."

Coalition against Trafficking in WomenAsia Pacific. Sex:from intimacy to "sexual labour" or is it a human right to prosti

tute?

http://www.uri.edu/artsci/wms/

hughes/catw/sexhtm [September 8 ,

1998]

A focus on the controversial debate about the "human right to prostitute." The economic side of selling sex is explored, including the claim that the in dustry does produce huge profits. Vari0us viewpoints are discussed, including the pro-prostitution stance, which argues for the right to self-determination, the right to work, and the right to freedom of expression.

The Commission on the Status of Women 42nd session, UN Headquarters, 2-13 March 1998.

http://www.un.org/womenwatch/ daw / csw /42sess.htm\#official [September 20, 1998]

A report on a recent session held to assess areas of concern critical to the Beijing Platform for Action: the Girlchild, Women and Armed Conflict, Violence against Women, and the Human Rights of Women, as well as continued work on an optional Protocol for CEDAW.

Communication of trafficking in womenfor the purpose of sexual exploitation. http://europa.eu.int/en/record/ other /womsum.htm\#c1

[September 10, 1998]

An exploration of the increasing trend of trafficking in women in Europe, the article discusses the idea of trafficking for the purpose of sexual exploitation. The discussion addresses the increase in European trafficking, as well as naming countries involved in global trafficking, and pinpointing the prime targets of the industry.

Derks, Annuska.1997. Tra.ffickingofCambodian women and children to Thailand. International Organization of Migra tion.

http:// www .iom.int (click on Publications; go to Books, Surveys, and Studies; click on Trafficking in Migrants and Other Forms ofIrregular Migration) [September 11, 1998] A study focusing on the recruitment process of Cambodian women and children being trafficked to Thailand, this piece attempts to provide greater insight 
into an industry which exists not only for the purpose of prostitution, but also to supply labour for construction, fishing, and domestic work. Other aspects of the trafficking phenomenon are explored, including transportation, employment, arrest, and the possibility of return to Cambodia.

Foundation orWomen's Forum/Stitelson Kvinnoforum, Stoc tholm. August 1998. Traficking in Women for the Purpase of Sexual Exploitation: Mapping the Situation and Existing Organizations Working in Belarus, Russia, the Baltic and Nordic States.

http:/ / www.qweb.kvinnoforum.se/ papers/traffickingreport.html [September 28, 1998]

This report by the Foundation of Women's Forum is a thorough documentation of research concerning trafficking in women. Having surveyed two hundredNGOs, government institutes, and research agencies in the region, the forum concludes that lack of action toend trafficking is a problem which plagues European alliances. The forum identifies possible strategies to combat trafficking, and reports on current programs, including links to the study's official website (questionnaires are available).

Hughes, Donna M. 1997. "Trafickingand sexual exploitation on the Internet." Feminsta! (Online Journal of Feminist Construction) 1 no. 8.

http://www.feminista.com/v1n8/

hughes.html

[August 30, 1998]

The article explores the dangerous avenues for trafficking and sexual exploitation opened up by the Internet, including bride trafficking, sex tours, promotion, exchange of information, and live conferencing. It acts as an illustration of the ways in which new technology can be to promote global trafficking and the sexual exploitation of women.

The International Organization for Migration. 1995. Thaficking and prostitution: the growing exploitation of migrant mamen frem Control and Eatern Europe.
Brussels: The International Organization for Migration.

http:/ / www.iom.int/www/iom/ publications/books_studies_surveys/ mip_traff_women_eng.htm

[September 15, 1998]

An examination of the increase in the number of migrant women being trafficked from Central and Eastern Europe, the article begins with a description of several women's experiences, followed by a discussion of the differences between trafficking from Central and Eastern Europe to trafficking from other developing countries. The study concludes with suggestions for steps to be taken, in order to fight trafficking in Central and Eastern Europe.

The International Organization for Migration. 1996. Trafficking in women from the Dominican Republic for sexual exploitation.

http:/ / www.iom.int (click on Publications; go to Books, Surveys, and Studies; click on Trafficking in Migrants and Other Forms of Irregular Migration)

[September 10,1998]

This article explores the growing phenomenon of women migrating for prostitution. A discussion of the problem is undertaken through a presentation of interviews with trafficked women, representatives of a major NGO, social workers, and several government authorities. The causes underlying an increase in trafficking are explored, as are the ways in which women become involved in this industry, the countries commonly "chosen" as destinations, and the consequences faced by women upon a return to theirhomecountry. The article concludes with a discussion of several policy recommendations forwarded recently in the Dominican Republic, as part of an effort to fight the wave of migration.

The International Organization for Migration. 1996. Traficking in women to Italy for sexual exploitation.

http://www.iom.int (click on Publications; go to Books, Surveys, and Studies; click on Trafficking in Migrants and Other Forms of Irregular Migration)

[September 10, 1998]
Adescription of trafficking in women to Italy, the article explores various ways in which women are recruited and transported, controlled and exploited. Integral to this discussion is an examination of the role of traffickers.

The International Organization for Migration. 1996. Trafficking in women to Austria for sexual exploitation. Brussels: International Organization for Migration. http:/ / www.iom.int (click on Publications; go to Books, Surveys, and Studies; click on Trafficking in Migrants and Other Forms of Irregular Migration)

[September 20, 1998]

An analysis of trafficking in women to Austria, the article explores the socioeconomic context of prostitution in this European country. Interviews with prostitutes shed light on the realities of trafficked women, including the ways in which women are contacted in foreign countries and how they come to be involved in prostitution in Austria. Prostitution is discussed within a legal framework, as is the significance of a recently established, ministerial group committed toconfronting the problem of trafficking in Austria.

Leidholdt, Dorchen. 1998. Prostitution: $A$ Contemporary Form of Slavery. UNWorking Group on Contemporary Forms of Slavery.

http://www.uri.edu/artsci/wms/ hughes/catw/slavery.htm [September 8, 1998]

Offering a working definition of sexual exploitation, the author establishes prostitution as a form of slavery and makes a clear, significant distinction between "forced" and "voluntary" prostitution. The work of the Coalition is also discussed.

McGirk, Tim. 1997. “Nepal's Lost Daughters: India's Soiled Goods." Time 149, no. 4, 27 January 1997.

http://cgi.pathfinder.com/time/

magazine/1997/int/970127/

asia.nepals_lost.html

[September 20, 1998]

Adiscussion of trafficking in the Indian subcontinent, this article describes the difficult reality faced by young Nepa- 
lese village girls sold into prostitution in India. Upon contracting the AIDS virus or the "Bombay disease," many girls return home to die, and find themselves ostracized by the people of their villages. The plight of such girls is detailed, in the hopes of illustrating what the Nepalese law is lacking, as well as highlighting necessary changes.

Menon, Meena. 1997. "Victims of the Dark." The Hindu Online, 29 September 1997.

http://decaf.javanet.com/nepal/

victims-dark.html

[August 31, 1998]

Describing the conditions in which the prostitutes of Bombay live, the author discusses the sexual exploitation and trafficking rampant in this Indian city. Included is a brief summary of the strategies being employed at present to fight trafficking. Throughout the article, the author reinforces her belief in a longterm rehabilitation strategy.

Nimalka, Fernando. 1998. Trafficking in Asia-an overview.

http://www.imadr.org/eng/forum.

html\#top_doc

[September 9, 1998]
In this overview of trafficking in women in Asia, the author describes the conditions which allow the trafficking ind ustry to flourish. A discussion of the very concept of "trafficking" is included, as is an excerpt from the Platform of Action in the Beijing Declaration.

Specter, Michael. 1998. "Trafficker's New Cargo: Naive Slavic Women." New York

Times, Sunday, 11 January 1998.

http://www.brama.com/issues/

nytart.html

[September 10, 1998]

Offering a description of the global trafficking of poor Slavic women, the article explores reasons for the growth in trafficking in this part of the world. The argument is made that the Ukraine and its Slavic neighbours have replaced Thailand and the Philippines as centres of global trafficking.

Yayori, Matsui. 1998. Eliminating Traf ficking in Asian Women.

http://www.alternatives.com/crime /

ASIAWOM.html

[September 10, 1998]

A discussion of changes in the trafficking

of women which have occurred in
Japan during the last decade, including the transition from foreign "sex tours" frequented by Japanese men to an influx of Asian women into the domestic sex industry. Illustrating the plight of various women trafficked to Japan, the author also explores the underlying reasons for an increase in trafficking of women in Asia by examining other countries, including Thailand and the Philippines. In conclusion, the author discusses the emergence of relief organizations created to tackle the problem in Japan.

Y oungyik, Y

oon.I998.InternationaISexual

Slavery.

http://www.alternatives.com/crime /

part7.html

[September 10, 1998]

A focus on the international aspects of trafficking in women, the article discusses various methods employed to recruit women for prostitution and the possible reasons for favouring foreign women. The domestic laws of such countries as China, Brazil and the United States, which prohibit trafficking and prostitution, are explored, as are international prohibitions.

\title{
BreakiDg Ground: The 1956 Hungarian Immigration to Canada Edited by
}

\author{
Robert H. Keyserlingk
}

Toronto: York Lanes Press, 1993; ISBN 1-55014-232wl; 117 pages, \$6.99

This book is a collection of personal and archival-based memories on the selection, transport and settlement of about 40,000 Hungarian refugees in Canada in one year. It is a source of primary record as well as scholarly reflection on one of the most significant refugee movements to Canada after World War II-the 1956 Hungarian refugee movement. Based on papers that were presented at a 1990 conference, the authors touch on the unique political, administrative and settlement features of this movement. The resulting work, edited by Professor Keyserlingk, is a unique mix of personal reminiscences and academic scholarship.

Available from:

Centre for Refugee Studies

Fax: (416) 736-5837 • Email: refuge@yorku.ca 


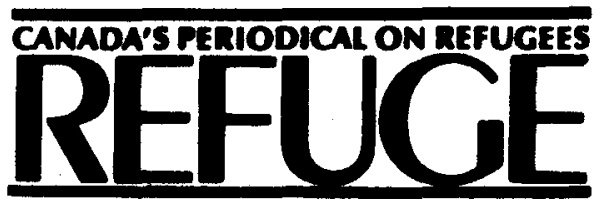

$$
\text { Refuge }
$$

Centre for Refugee Studies Suite 322, York Lanes York University 4700 Keele Street, Toronto Ontario, Canada M3J 1P3

Phone: (416) 736-5663

Fax: (416) 736-5837

Email: refuge@yorku.ca

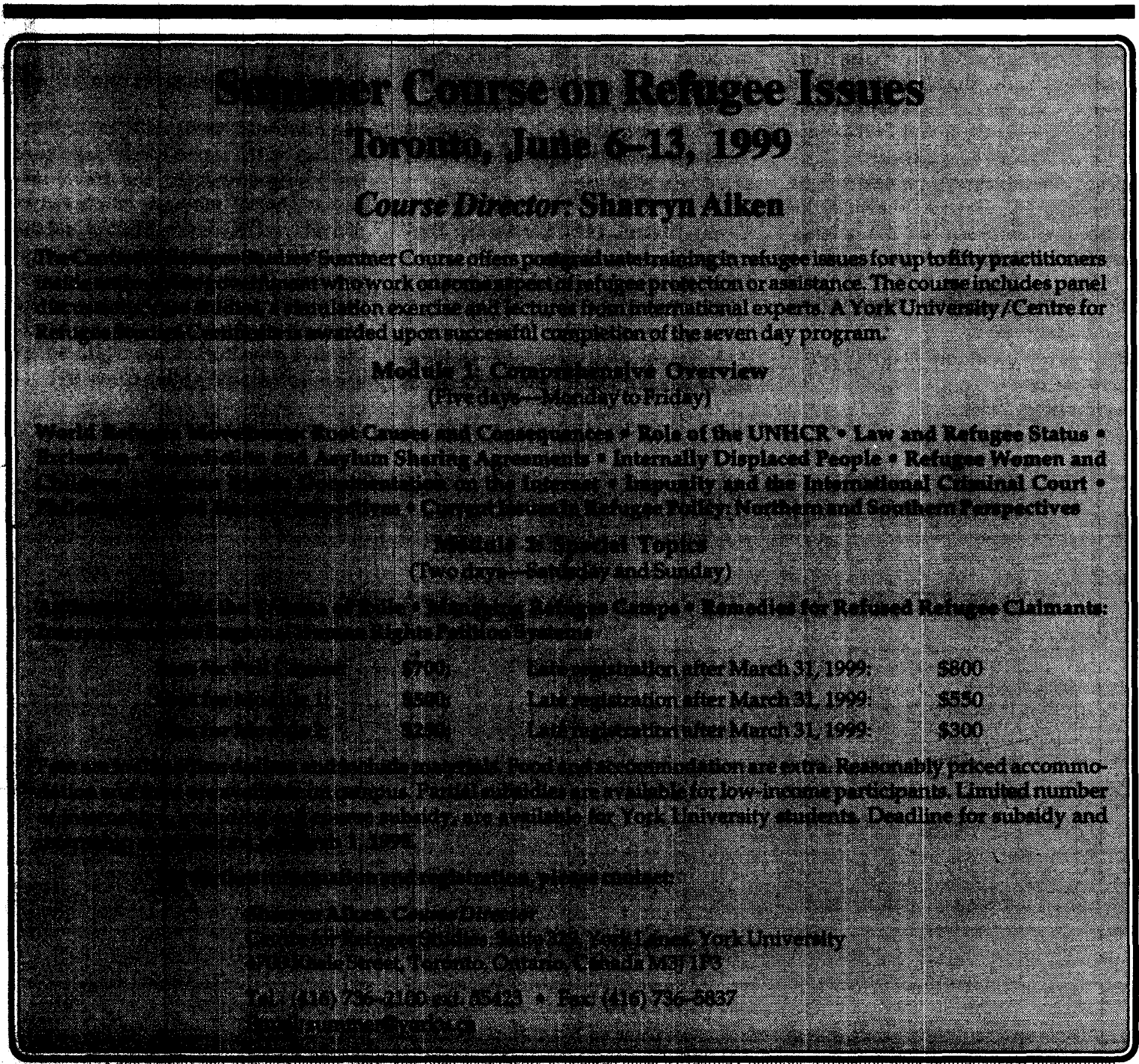

License, which permits use, reproduction and distribution in any medium for non-commercial purposes, provided the original author(s)

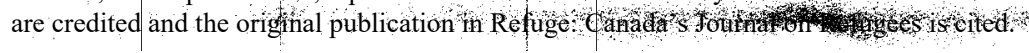

